\title{
Whale distribution in relation to prey abundance and oceanographic processes in shelf waters of the Western Antarctic Peninsula
}

\author{
Ari S. Friedlaender ${ }^{1, *}$, Pat N. Halpin' ${ }^{1}$, Song S. Qian ${ }^{2}$, Gareth L. Lawson ${ }^{3}$, \\ Peter H. Wiebe ${ }^{3}$, Deb Thiele ${ }^{4}$, Andrew J. Read ${ }^{1}$ \\ ${ }^{1}$ Duke University Marine Laboratory, 135 Pivers Island Road, Beaufort, North Carolina 28516, USA \\ ${ }^{2}$ Nicholas School of the Environment and Earth Sciences, Duke University, Durham, North Carolina 27708, USA \\ ${ }^{3}$ Woods Hole Oceanographic Institution, Woods Hole, Massachusetts 02543, USA \\ ${ }^{4}$ Deakin University, School of Ecology and Environment, Warrnambool, Victoria 3280, Australia
}

\begin{abstract}
The Western Antarctic Peninsula (WAP) is a biologically rich area supporting large standing stocks of krill and top predators (including whales, seals and seabirds). Physical forcing greatly affects productivity, recruitment, survival and distribution of krill in this area. In turn, such interactions are likely to affect the distribution of baleen whales. The Southern Ocean GLOBEC research program aims to explore the relationships and interactions between the environment, krill and predators around Marguerite Bay (WAP) in autumn 2001 and 2002. Bathymetric and environmental variables including acoustic backscattering as an indicator of prey abundance were used to model whale distribution patterns. We used an iterative approach employing (1) classification and regression tree (CART) models to identify oceanographic and ecological variables contributing to variability in humpback Megaptera novaeangliae and minke Balaenoptera acutorstrata whale distribution, and (2) generalized additive models (GAMs) to elucidate functional ecological relationships between these variables and whale distribution. The CART models indicated that the cetacean distribution was tightly coupled with zooplankton acoustic volume backscatter in the upper (25 to $100 \mathrm{~m}$ ), and middle (100 to $300 \mathrm{~m}$ ) portions of the water column. Whale distribution was also related to distance from the ice edge and bathymetric slope. The GAMs indicated a persistent, strong, positive relationship between increasing zooplankton volume and whale relative abundance. Furthermore, there was a lower limit for averaged acoustic volume backscatter of zooplankton below which the relationship between whales and prey was not significant. The GAMs also supported an annual relationship between whale distribution, distance from the ice edge and bathymetric slope, suggesting that these are important features for aggregating prey. Our results demonstrate that during the 2 yr study, whales were consistently and predictably associated with the distribution of zooplankton. Thus, humpback and minke whales may be able to locate physical features and oceanographic processes that enhance prey aggregation.
\end{abstract}

KEY WORDS: Whale distribution $\cdot$ Zooplankton $\cdot$ Ice edge $\cdot$ Antarctica $\cdot$ SO GLOBEC $\cdot$ CART $\cdot$ GAM

Resale or republication not permitted without written consent of the publisher

\section{INTRODUCTION}

The Western Antarctic Peninsula (WAP) is a biologically rich area known to support a persistent and large standing stock of Antarctic krill Euphausia superba (Marr 1962, Lascara et al. 1999) and large populations of top predators, including baleen whales, that depend entirely or to a large extent on Antarctic krill as a food resource (Laws 1977, Hofmann et al. 2002). Physical forcing mechanisms determine, at least in part, patterns of productivity, recruitment, survival and the distribution of krill (Loeb et al. 1997, Nicol et al. 2000). Krill are tightly coupled with the marginal ice edge zone, foraging on sea ice algae in the summer, and 
relying on the under ice habitat to overwinter and as refuge from predators (Brierley et al. 2002). Similarly, the distribution of krill predators has been linked to areas around sea ice margins (de la Mare 1997, Ainley et al. 1998, van Franeker et al. 2002, Thiele et al. 2004).

Climate variability affects marine ecosystems at both physical and biological levels, and many species have evolved complex life history strategies to cope with environmental change (Johnston et al. 2005a). The climate of the WAP is warming rapidly and, as a result, the extent and duration of winter sea ice are being reduced (Parkinson 2002). Several studies have linked the extent of winter sea ice to krill abundance patterns and survival rates and have shown krill density to be declining over large scales (Atkinson et al. 2004). Thus, interannual changes in sea ice extent affect the recruitment and distribution patterns of Antarctic krill (Loeb et al. 1997), and potentially those of their predators.

Oceanographic features and processes that physically aggregate prey may increase the foraging efficiency of top predators (Croxall et al. 1985). Such forcing mechanisms probably affect the fitness, timing of migrations, and distribution of baleen whales (de la Mare 1997, Tynan 1998). Most baleen whale species in the Southern Hemisphere undertake extensive seasonal migrations from tropical breeding grounds to the rich and productive waters around the Antarctic continent in summer to forage and store energy (Tynan 1998, Reid et al. 2000) and, with few exceptions, forage almost exclusively on Antarctic krill (Mackintosh 1965, Kawamura 1994). Because of their dependence on a single prey item that is heavily influenced by physical forcing, the dynamics of krill predators are tightly coupled with variation in krill availability (Murphy 1995, Fraser \& Hofmann 2003, Reid et al. 2005). However, to date there have been very few studies linking the distribution of prey to the spatial ecology of baleen whales in this ecosystem.

The primary objective of the Southern Ocean Global Ocean Ecosystems Dynamics Program (SO GLOBEC) is 'to understand the physical and biological factors that contribute to enhanced Antarctic krill growth, reproduction, recruitment, and survivorship throughout the year' (Hofmann et al. 2002). Scientific programs pursuing this objective include studies of the habitat, prey and predators of Antarctic krill. This program has relied heavily on newly emerging technologies and multidisciplinary research ventures to test specific hypotheses regarding interactions between the environment, krill and predators (Hofmann et al. 2002).

Because they require dense and predictable prey aggregations for effective foraging, baleen whales are good indicators of oceanographic productivity (Moore et al. 2002). There is a growing literature describing and modeling the distribution patterns of cetaceans in relation to environmental features and oceanographic processes. Early reports used whaling catch data to describe relationships between whaling grounds and large-scale hydrographic conditions in the Southern Ocean (Uda 1954) and North Pacific (Nasu 1974). More recent studies have combined oceanographic and prey measurements to describe the habitats of large whales (e.g. Woodley \& Gaskin 1996, Murase et al. 2002). In addition, spatially explicit analytical techniques are now being used to quantify distribution patterns, generate predictive habitat models, and assess habitat utilization patterns of cetaceans (e.g. Hastie et al. 2005, Tynan et al. 2005). Unfortunately, the majority of these studies have relied on physical environmental features and do not include direct measures of prey availability.

Interdisciplinary approaches to understanding cetacean distribution patterns have incorporated knowledge of hydrographic features (Tynan 1997, Johnston et al. 2005b) and associations with productivity and prey (Woodley \& Gaskin 1996, Murase et al. 2002). However, many studies average environmental variables over coarse spatial and temporal scales, leading to decreased levels of resolution, and are thus unable to examine the importance of localized oceanographic dynamics in their models (Tynan et al. 2005). Presently, synoptic research programs (e.g. US Northeast Pacific and SO GLOBEC) are generating data sets that allow a better understanding of fine-scale hydrographic and biophysical processes in marine systems. To understand the ecology of cetaceans in a dynamic and changing environment, we must understand the pertinent environmental features that affect distribution patterns at a variety of scales. Ideally, such models should have both within-year explanatory value and interannual predictive power (Hastie et al. 2005).

Studies concerning whales in the Antarctic have largely been limited to describing distribution patterns in relation to large scale oceanographic features (Uda 1954, Tynan 1998) or coarse surveys of prey across broad spatial scales (Kasamatsu et al. 2000a,b, Nicol et al. 2000, Reid et al. 2000, Murase et al. 2002). Such relationships have not been assessed at smaller spatial extents (10s of $\mathrm{km}$ ) (Thiele et al. 2004). High densities of krill, baleen whales and other predators do occur at ice margins or edges (de la Mare 1997, Brierley et al. 2002), particularly where they coincide with physical features and biological processes (i.e. complex bathymetry, gyres, eddies, shelf edges) that may enhance concentrations of nutrients and prey (Ribic et al. 1991, Murase et al. 2002, Thiele et al. 2004).

Ecological relationships between predators and their prey should be measured as concurrently as possible. In this study, we aimed to determine the nature of the relationship between baleen whales (humpback Megaptera novaeangliae and minke Balaenoptera acutorstrata) and their prey (Antarctic krill). In addi- 
tion, measurements of the dynamic oceanographic processes that affect the distribution of krill are necessary to understanding the spatial response of their predators. Therefore, the goal of the present study was to model the distribution patterns of baleen whales in the inner shelf waters of the WAP in relation to environmental predictor variables and concurrent hydroacoustic measurements of prey made during SO GLOBEC field studies, and evaluate how these relationships may be useful in forecasting cetacean distribution patterns between years. We hypothesized that the distribution of cetaceans would be most closely related to the distribution of Antarctic krill, and to a lesser extent to the physical forcing features that may act to aggregate krill over broad and meso-scales around Marguerite Bay in the WAP.

\section{MATERIALS AND METHODS}

Data collection. Data were collected as part of the Southern Ocean GLOBEC program in and around the continental shelf waters of Marguerite Bay on the western side of the Antarctic Peninsula (Fig. 1B), between April and June 2001 and 2002. Environmental and whale sighting data were collected from aboard the ARSV 'Laurence M. Gould' (LMG) and the RVIB 'Nathaniel B. Palmer' (NBP). Multi-disciplinary oceanographic sampling from the NBP was conducted along pre-determined cross-shelf sampling stations spaced $40 \mathrm{~km}$ apart and oriented perpendicular to the coast (Fig. 1), whereas the LMG transited between process sites for fine-scale sampling and experimental activities.

Cetacean surveys. Visual surveys for cetaceans were conducted on 3 cruises: from the NBP between 4 April and 1 June 2001 and from the NBP and LMG between 11 April and 19 May 2002. Trained observers worked from each vessel while underway along the survey grid, between process stations and other sites, or otherwise in transit. Each observer searched in $90^{\circ}$ sweep from the bow of the ship to the perpendicular beam with the naked eye or using $7 \times 50$ Fujinon binoculars. In addition, $20 \times 50$ image stabilized Zeiss binoculars were used to aid in species identification. Data were recorded on a laptop computer using a Windowsbased sighting program (WinCruz Antarctic) that continuously logged the ship's position, course and speed. Observers initially recorded environmental and sighting conditions (weather, visibility, glare, swell height, Beaufort sea state, sea ice concentrations) and tracked changes as these occurred. Cetacean sightings were logged with a time and position stamp, distance and bearing from the ship, species identification, group size (high, low and best estimate), presence of sea ice,

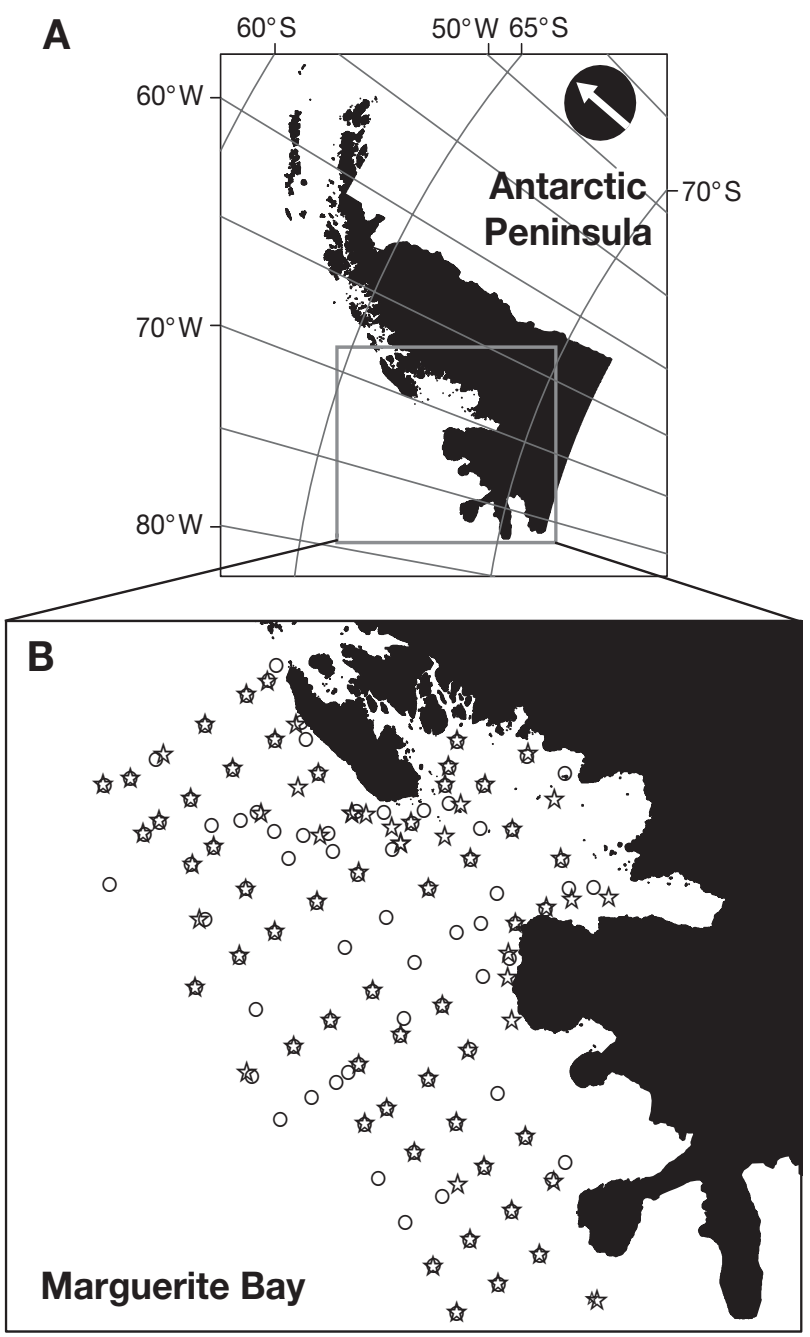

Fig. 1. Antarctic Peninsula, showing SO GLOBEC (A) study area (boxed) (B) and sampling stations in Marguerite Bay visited by RVIB 'Nathanial B. Palmer' in fall. (放) 2001; (O) 2002

behavior, sighting cue and other comments. As noted in Thiele et al. (2004), most whales in the Antarctic are medium to large species, and thus can be detected at relatively high Beaufort sea states. Survey effort was abandoned when conditions were determined by the observer to have deteriorated enough (>Sea State 5 ) to preclude the detection of most species: e.g. strong winds, fog or reduced visibility, large swell, etc. The on-effort cruise track was divided into 30 min sections. For all analyses, the total number of whales sighted (using the best estimate numbers) in each 30 min block of survey effort was used as the response variable. Distance covered in these effort blocks was typically 2 to 3 nautical miles, as the ship's speed was dictated by towing of the hydro acoustic gear (see next subsection). This enabled testing of how the environmental variables affected (and best predicted) the total number of whales seen per survey unit. 
Environmental data. Hydrographic data were collected from the NBP in the autumn of both 2001 and 2002. Sampling stations were designed to provide coverage of the continental shelf to the north and south of Marguerite Bay (Klinck et al. 2004). In 2001, 81 stations were sampled, with each station 10 to $40 \mathrm{~km}$ apart. In 2002, 92 stations were sampled, with weather and ice conditions being a limiting factor (Fig. 1B). Hydrographic measurements were made using a SeaBird 911+ Niskin/rosette conductivity-temperature-depth (CTD) sensor system. Water samples were taken at a range of depths throughout the water column (See Klinck et al. 2004 for a detailed description). Surface water samples from all stations were used to determine $\mathrm{chl}$ a concentrations $\left(\mathrm{g} \mathrm{m}^{-3}\right)$. Deep temperature maxima below $200 \mathrm{~m}$ were used to define and categorize water masses (Chapman et al. 2004). Bottom depth for transects and sightings was calculated from a bathymetry grid used in Bolmer et al. (2004).

We use the ice edge information collected and used by Chapman et al. (2004). The marginal sea ice edge in and around Marguerite Bay was determined for each cruise as the transition zone where sea ice covered more than $15 \%$ of the ocean surface (Zwally et al. 1983). Observers recorded ice conditions initially and whenever these changed, allowing us to reconstruct the ice edge from visual effort. In the event that ice information was lacking from direct visual observation, weekly sea-ice concentration satellite imagery was considered (National/Naval Ice Center (2002): www.natice.noaa.gov).

Quantitative acoustic surveys were conducted using the Bio-Optical Multi-frequency Acoustical and Physical Environmental Records (BIOMAPER-II) (Wiebe et al. 2002) to assess the spatial distribution of zooplankton. BIOMAPER-II collected acoustic data from 5 pairs of upward and downward looking transducers with frequencies of 43, 120, 200, 420 and $1000 \mathrm{kHz}$ (Lawson et al. 2004). The instrument was towed behind the NBP up and down between 20 and $300 \mathrm{~m}$ depth at a survey speed of 4 to 6 knots. Acoustic data from both upward and downward looking transducers were combined to provide a vertically continuous record of the water column. Volume backscattering strength at $120 \mathrm{kHz}$ (henceforth referred to simply as 'backscattering') was recorded in $1.5 \mathrm{~m}$ depth bins with a horizontal resolution of ca. $35 \mathrm{~m}$ (Lawson et al. 2004). For spatial analysis, measurements of integrated backscattering were binned into 25 to 100 (shallow layer) and 100 to $300 \mathrm{~m}$ (mid-water), depth ranges, encompassing the maximum measured dive depth for humpback whales (Hamilton et al. 1997). Backscattering was then averaged along the track line over $5 \mathrm{~km}$ along-track intervals centered at the mid-points of the $30 \mathrm{~min}$ whale observation legs. To better approximate a normal distribution, backscatter data were log-transformed into decibel form for parametric regression analyses (Lawson et al. 2004).

Backscattering is used here as a measure of the relative abundance of prey. In addition to target abundance, however, backscattering is related to the acoustic frequency and the size of targets, as well as their efficiency in reflecting sound and thereby the taxonomic composition of animals present. Thus, we must be aware of these confounding influences when using backscattering to examine patterns in zooplankton and micronekton biomass (Lawson et al. 2004). The frequency examined here, $120 \mathrm{kHz}$, is optimal for detecting larger zooplankton and micronekton such as krill. Furthermore, given the large spatial changes in backscattering and the predominant zooplankton taxa present in the study area, the confounding effects on backscattering of sound scattering efficiency and taxonomic composition are likely to be minimized (see Lawson et al. 2004 for further discussion). In regions where cetacean sightings did not directly overlap with BIOMAPER II acoustic measurements, an inverse distance weighted interpolation was run on volume backscatter using similar grid cell sizes of $2.5 \mathrm{~km}^{2}$. We then sampled the interpolated grid at the whale sighting locations.

All hydrographic, bathymetric and backscatter data were imported into ArcGIS v8.3 for analysis (ESRI 2001). Point coverages of bathymetry, deep temperature maximum, surface chl a concentrations, and backscatter were used to create interpolated raster surfaces across the study area. For our interpolations, we used the ArcGIS inverse distance weighting function that determines cell values using linearly weighted combinations of a set of sample points. We chose a cell size of $1000 \mathrm{~m}$ for all environmental variables and distance matrices, with the above noted exceptions of volume backscatter and bathymetry data. This cell size allowed us to track changes in measured features across the spatial extent of the Marguerite Bay study area. We calculated bathymetric slope as the angular degree of change between the shallowest and deepest point in a grid cell, and generated a coverage to reflect these values. We then created Euclidean distance matrices using the 'spatial analyst' function in ArcGIS to sample the minimum distance of whales from the coast, marginal ice edge, high bathymetric slope, and inner shelf water boundary. Sampling units and methods for all environmental variables considered are given in Table 1.

Modeling whale distribution patterns. In order to gain statistical power, we evaluated distribution and occurrence relative to oceanographic processes and prey characteristics for both humpback and minke whales combined. These 2 species were the most com- 
Table 1. The unit of measure, and sampling method for each environmental variable collected during SO GLOBEC and used in CART models and GAMs of cetacean distribution patterns

\begin{tabular}{|c|c|c|}
\hline Environmental variable & Units & Method \\
\hline Acoustic volume backscatter 25 to $100 \mathrm{~m}$ & $\mathrm{db}$ & Continuous along track and interpolated fields \\
\hline 100 to $300 \mathrm{~m}$ & $\mathrm{db}$ & Continuous along track and interpolated fields \\
\hline Chlorophyll a & $\mathrm{g} \mathrm{m}^{-3}$ & Interpolated grids from sampling stations \\
\hline Bathymetry & $\mathrm{m}$ & Bathymetry grid (Bolmer et al. 2004) \\
\hline Slope of bathymetry & Degree change/grid cell & Grid cells calculated from bathymetry grid \\
\hline Water temp. max. below $200 \mathrm{~m}$ & ${ }^{\circ} \mathrm{C}$ & Interpolated grids from sampling stations \\
\hline Distance from coast & $\mathrm{m}$ & Straight line distance grids \\
\hline ice edge & $\mathrm{m}$ & Straight line distance grids \\
\hline high slope & $\mathrm{m}$ & Straight line distance grids \\
\hline inner shelf water boundary & $\mathrm{m}$ & $\begin{array}{l}\text { Straight line distance grids from reclassified deep } \\
\text { temp. max. }\end{array}$ \\
\hline
\end{tabular}

monly sighted during the SO GLOBEC program, and tended to be found in similar areas (Thiele et al. 2004). Furthermore, both species are krill predators in the Antarctic (Matthews 1937, Ichii \& Kato 1991), and may use similar means for detection and distribution themselves in relation to prey. Previous studies have also found simple correlations between concentrations of both minke and humpback whales with large aggregations of euphausiids (Murase et al. 2002). Also, with the goal of determining the relationships between krill predators and their prey, we felt justified in pooling sightings of both minke and humpback whales for analysis. The number of sightings and total number of whales observed were calculated for every $30 \mathrm{~min}$ of sighting effort. We then determined values for each concurrent environmental variable layer at all locations where whales were sighted, as well within each 30 min effort leg in which cetaceans were not seen.

We used an iterative process that employed both classification and regression trees (CARTs, Breiman et al. 1984) and generalized additive models (GAMs, Hastie \& Tibshirani 1990) to explore the environmental factors that might have affected the distribution patterns of whales. We used tree-based regression models as an exploratory technique to uncover structure within the data and to identify variables that contributed significantly to variation in cetacean distributions. We then used the variables identified from the CART model to fit a GAM. The GAM is an exploratory data analysis tool for elucidating functional forms of relationships between observations and predictor variables (Hastie \& Tibshirani 1990). GAMs are very useful for interpreting, ecological interactions as they are able to fit non-parametric functions to estimate the relationship between response and predictor variables without imposing limitations of any underlying relationships (Hastie et al. 2005). They can be used to assess how each environmental variable (controlling for the effects of other variables) relates to varying relative abundances of cetaceans.
Tree-based hierarchical models, such as CART, are based on binary, recursive, portioning methods which aim to resolve relationships to response variables by recursively partitioning data into increasingly homogeneous subgroups (Breiman et al. 1984). CART models can handle a broad range of response types, are invariant to monotonic transformations of the explanatory variables, are easy to construct and interpret, can interpret missing values in both response and explanatory variables, and are able to capture interaction effects among predictor variables (De'ath and Fabricius 2000). CART models are also an attractive analytical tool because, unlike linear models, they do not assume an a priori relationship between the response variable and predictor variables; rather, the data are divided into several groups where each has a different predicted value of the response variable (Guisan \& Zimmerman 2000, Redfern et al. 2006). Although CART has been used in marine ecological studies primarily for developing predictive models, as with most nonparametric statistical tools, it is more suitable as an exploratory data analysis tool, since it results in a discontinuous prediction surface that may not be scientifically defensible. When the underlying relationship between the response and the predictor is close to linear, CART can be extremely inefficient. As a result, it is often used as a variable selection method. Qian \& Anderson (1999) illustrated the use of CART for identifying predictor variables that contribute significantly to variation in response variables. They described such use of CART as 'ANOVA in reverse'.

To identify environmental variables to include in the GAM, we conducted a Poisson (regression) CART analysis on the combined 2001 and 2002 sighting effort data (using the RPART package under R). The number of variables selected from the CART was determined by whether the sequential splits or nodes continued to reduce the model's predictive error. Specific environmental variables were then selected that significantly improved the model at the primary and later 
splits of the data. We chose a combination of variables identified by the CART as well as some competing variables at the primary split. These latter variables help capture the non-additive relationship to whale numbers, i.e. before the compounding influence of multiple variables.

The selected predictor variables are used to fit GAM models, using the mgcv package under R (Wood 2004). Graphic output of the GAM provides a visual representation of the relationships between variables. The shape and significance of the relationship of each variable allowed us to describe or hypothesize how parameters affected the whales relative abundance. $\mathrm{R}^{2}$ is calculated as the fraction of deviance explained by the model (1-residual deviance/null deviance). The significance of the $\mathrm{p}$-value of each term was based on the chi-square test of comparing the full model and the model omitting the respective predictor. We then used the percentage of deviance explained to evaluate the within-year predictive ability of the models' variables. Finally, to assess the predictive power of the identified environmental variables and their relationship to cetacean distribution and relative abundance between years, we ran the GAM using individual years of data from SO GLOBEC.

\section{RESULTS}

\section{Cetacean surveys}

During autumn 2001, we conducted $59.5 \mathrm{~h}$ of cetacean surveys across the northern and southern shelf waters, as well as within the mouth and inner reaches of Marguerite Bay (Table 2, Fig. 2). Survey effort was made throughout the SO GLOBEC study area, reaching the continental shelf break and inner portions of Marguerite Bay. Humpback and minke whales were the only balaenopterid cetacean species sighted within the survey area. A total of 54 group sightings were made (32 humpback and 22 minke whales) in 2001, comprising 96 whales (61 humpbacks and 35 minkes) (Table 2, Fig. 3a).

In autumn 2002, with the addition of observers on a second vessel, cetacean surveys covered a greater por-

Table 2. SO GLOBEC cetacean sighting effort and sightings in 2001 and 2002 within Marguerite Bay study area. Ind.: individuals

\begin{tabular}{|ccccccc|}
\hline Year & $\begin{array}{c}\text { Effort } \\
\text { legs }\end{array}$ & Time & \multicolumn{2}{c}{ Humpback } & \multicolumn{2}{c|}{ Minke } \\
& Groups & Ind. & Groups & Ind. \\
\hline 2001 & 119 & 59.5 & 32 & 61 & 22 & 35 \\
2002 & 325 & 162.5 & 52 & 162 & 17 & 44 \\
\hline
\end{tabular}

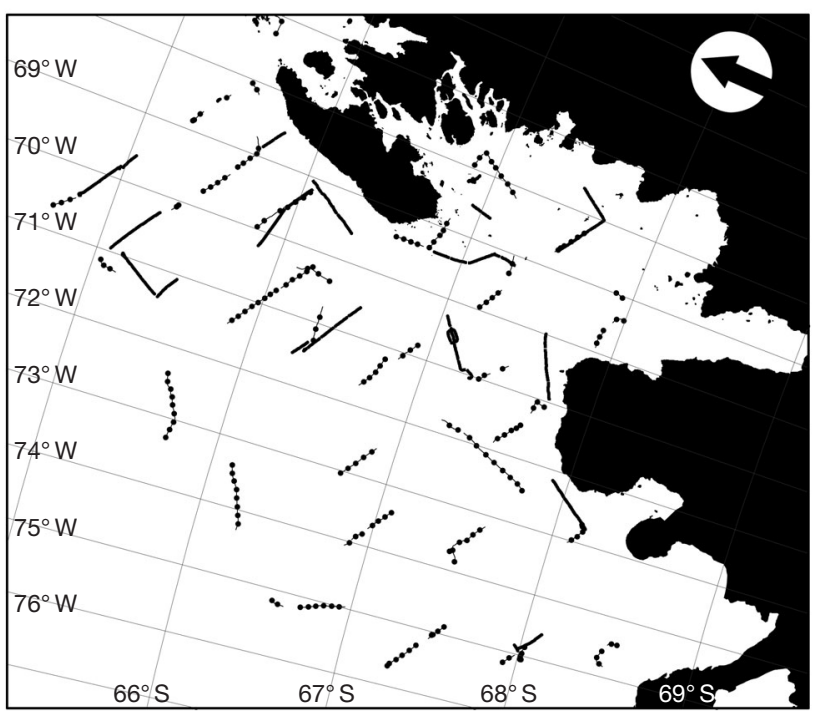

Fig. 2. Cetacean sighting survey effort in and around Marguerite Bay in fall of $2001(-)$ and $2002(\bullet \bullet \bullet)$

tion of the study area. A total of $162.5 \mathrm{~h}$ of sighting effort was made, covering the whole extent of the study area from inside Marguerite Bay, across the entire continental shelf area, and off the shelf break (Table 2, Fig. 2). A substantial amount of effort was made within Marguerite Bay-around the southern and eastern coasts of Adelaide Island, in and around Laubeuf Fiord and across the mouth of Marguerite Bay. In all, 69 sightings (52 humpback and 17 minke) were made within the survey area, comprising 206 whales (162 humpback and 44 minke) (Table 2, Fig. 3B).

\section{Tree-based models}

When both years of whale sighting data were combined for analysis, the CART maximized reduction in predictive error after 6 recursive splits, at which point the model's predictive error decreased to 0.7389 (Table 3). This value relates to the percentage of residual deviance explained by the model relative to the first split of the data. The 2 environmental variables that contributed most to the CART model were acoustic volume backscatter from 25 to $100 \mathrm{~m}$ and acoustic volume backscatter from 100 to $300 \mathrm{~m}$. At the level of the primary split, both these variables improved the overall CART model between 2 and 3 times more than any other variable, indicating their importance in affecting cetacean distributions. The other variables that improved the model's predictive ability were bathymetric slope, distance to the marginal ice edge, distance to the inner shelf water boundary and surface chl a concentration (Table 4). While these variables are not the same as those chosen at the first 6 


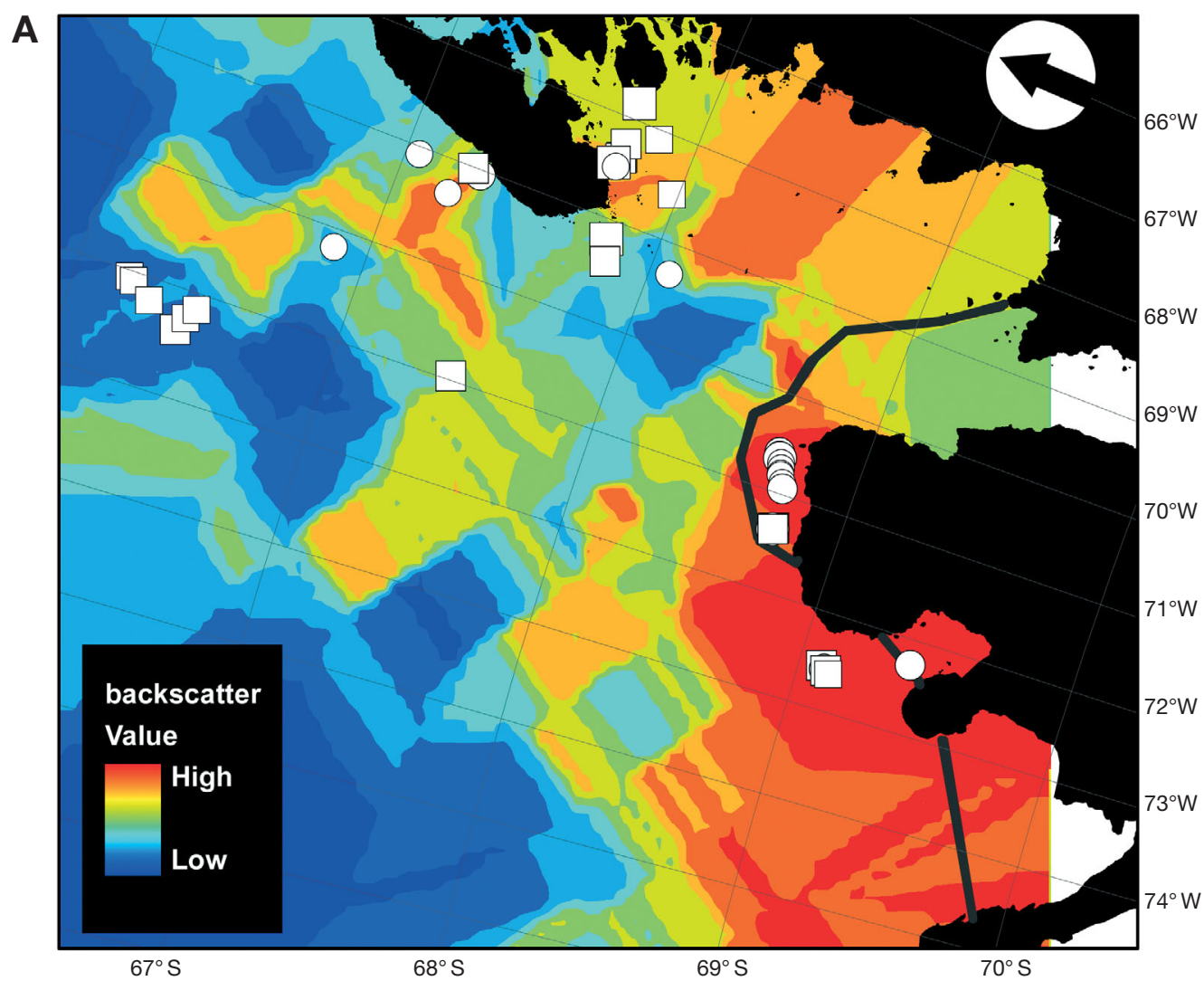

Fig. 3. Humpback ( $\square$ ) and minke $(\mathrm{O})$ whale sightings overlaid on interpolated grid of acoustic volume backscatter 25 to $100 \mathrm{~m}$ for (A) 2001 and (B) 2002 and marginal ice edge (-) Whale symbols scaled relative to best estimate of group size for each sighting. Interpolated zooplankton grids estimate total amount of acoustic volume backscatter (relative measure of zooplankton density) Blue areas have least zooplankton, and red areas most zooplankton. Note that white areas in far eastern reaches of Marguerite Bay and to the south are outside the interpolation range and should thus be interpreted as 'no data'

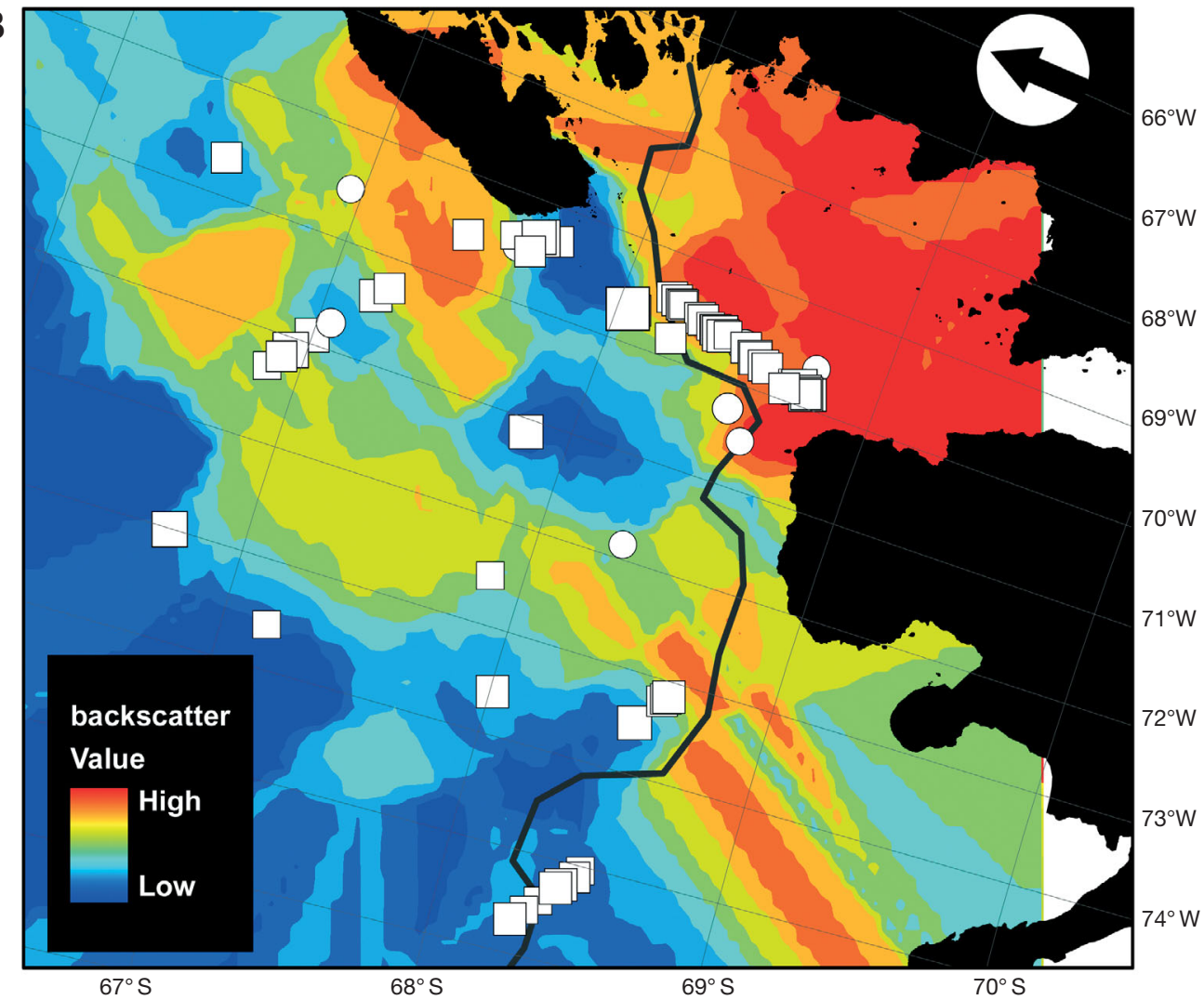


Table 3. CART model for cetacean distribution in relation to environmental variables in 2001 and 2002. The break indicates the number of splits after which the amount of residual deviance explained ceases to decrease and predictive power of model does not increase (i.e. error increases); percentage residual deviance explained by model relative to first split of data is underlined

\begin{tabular}{|cc|}
\hline Split & Residual deviance explained (x-error) \\
\hline 1 & 1.0146 \\
2 & 0.8651 \\
3 & 0.7761 \\
5 & 0.7574 \\
$\underline{6}$ & 0.7404 \\
8 & $\underline{0.7389}$ \\
9 & 0.7410 \\
& 0.7504 \\
\hline
\end{tabular}

splits by the CART (Fig. 4), they were nonetheless the most important initial, independent variables. At each recursive split in the tree-based model, the variable's contribution or improvement to the model is in relation to the features already identified. Thus, we chose the variables that initially (independent of other variables) had strong predictive ability for describing patterns in the whales, relative abundance (Table 4).

The primary split in the overall CART model occurred at a backscattering in the 25 to $100 \mathrm{~m}$ portion of the water column of $-79.775 \mathrm{~dB}$. A second split occurred at $-82.500 \mathrm{~dB}$ from 100 to $300 \mathrm{~m}$ (Fig. 4, Table 4). While the major function of the CART model in this study was to identify variables for further analysis in the GAM, it is useful to note where breaks in the variables occurred in relation to whale distribution.
Table 4. Environmental variables identified from CART model and used in GAMs to describe cetacean distribution patterns. Rank: initial, independent rank of each variable at first split in CART model. Variables in boldface are those used in GAM. Improvement: improvement to model score, associated with each variable split at which each value was generated

\begin{tabular}{|c|c|c|}
\hline Rank & Response variable & $\begin{array}{l}\text { Improvement } \\
\text { (Split No.) }\end{array}$ \\
\hline 1 & Volume backscatter dB 25 to $100 \mathrm{~m}$ (A.v100) & $249.38(1)$ \\
\hline 2 & Volume backscatter dB 100 to $300 \mathrm{~m}$ (A.v300) & $203.72(1)$ \\
\hline 3 & Bathymetry slope & $103.47(1)$ \\
\hline 4 & Distance to ice edge (Dist.ice) & $97.41(1)$ \\
\hline 5 & Distance to inner shelf water boundary (Dist.inswb) & $89.41(1)$ \\
\hline 6 & Chlorophyll a concentration (chla) & $102.51(3)$ \\
\hline 7 & Distance to coast & $132.77(6)$ \\
\hline 8 & Bathymetry & $130.52(6)$ \\
\hline
\end{tabular}

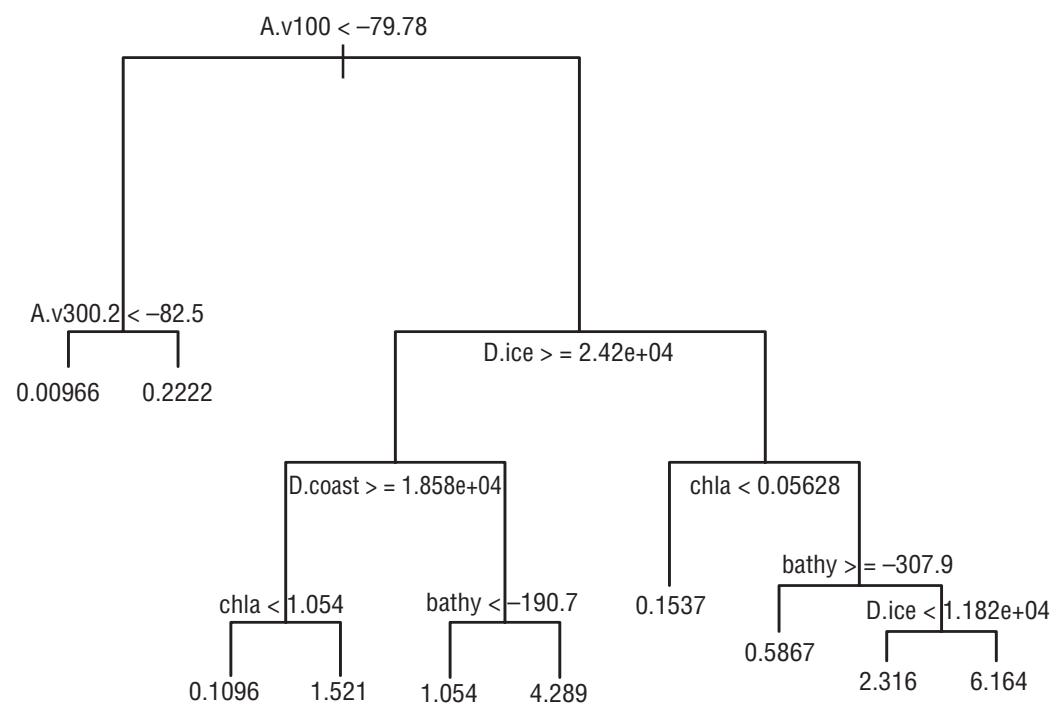

Fig. 4. Regression-based tree model of cetacean distribution in relation to environmental predictor variables; 6 splits are identified by their improvement to the overall model and contribution towards reducing predictive error, including 5 variables displayed in this tree (A.v: volume backscatter in $\mathrm{dB}$; bathy: bathymetry; chla: chlorophyll $a$; D.coast: distance to coast; D.ice: distance to ice)

\section{Generalized additive models}

The results of the generalized additive model suggest that the variables identified by the CART (acoustic volume backscatter in $\mathrm{dB}$ from 25 to $100 \mathrm{~m}$ and from 100 to $300 \mathrm{~m}$, bathymetric slope, distance to the marginal ice edge, distance to the inner shelf water boundary, and surface chl a concentration) were significantly $(\mathrm{p}<0.01)$ related to the distribution of whales during the combined 2001 and 2002 surveys (Table 5). The overall GAM explained $63.1 \%$ of the deviance in the whales' relative abundance. The model was significant $(p<0.003)$, and explained a larger amount of deviance (74.1\%) when run using data from 2002 only. However, the model run with 2001 data was more significant $(p<$ 0.001 ) and explained a large portion of deviance $(97.7 \%)$ (Table 5) in the observed whale distribution.

For the combined GAM, all variables had a significant relationship with whale density (Table 6). Of these, 4 variables (25 to $100 \mathrm{~m}$ acoustic volume backscatter, chl $a$, bathymetric slope and distance from the ice edge) were all highly significant $(\mathrm{p}<0.00001)$. Distance to the inner shelf water boundary was also significant in this model $(p<0.004)$; acoustic volume backscatter from 100 to $300 \mathrm{~m}$ was the least significant $(p<0.02)$. The number of whale sightings increased, as back- 
Table 5. Results of generalized additive models of relative abundance of cetaceans, including model significance and percentage of overall deviance explained. Full: data for 2001 and 2002 combined

\begin{tabular}{|llcc|}
\hline GAM model & $\mathrm{p}(>|t|)$ & $\mathrm{R}^{2}$ & Deviance explained (\%) \\
\hline Full & 0.01 & 0.408 & 63.1 \\
2001 & 0.001 & 0.977 & 97.7 \\
2002 & 0.003 & 0.436 & 74.1 \\
\hline
\end{tabular}

scatter values increased until a threshold value (near the mean) was reached (Fig. 5A). Likewise, the number of whale sightings was positively correlated with bathymetric slope. The number of whale sightings also decreased with increasing distance from the ice edge. While significant, there was no obvious relationship between whale sightings and distance to the inner shelf water boundary and chl a concentrations.

In 2001, the GAM showed generally relationships similar to those of the combined model, except that backscatter in the 100 to $300 \mathrm{~m}$ range $(\mathrm{p}<0.97)$ did not show a relationship with whale sightings (Table 6, Fig. 5B). Backscatter volume from 25 to $100 \mathrm{~m} \mathrm{(p<}$ $0.009)$ and distance to the marginal ice edge $(p<0.001)$ had the most influence on the relative abundance of whales during 2001. The distribution of cetacean sightings in relation to volume backscatter levels and the marginal ice edge zone are shown in Fig. 3A. The degree of bathymetric slope $(p<0.01)$ and proximity to the inner shelf water boundary $(p<0.02)$ also had significant impacts on whale distribution. Chl a concen-

Table 6. Contribution and significance (p) of environmental predictor variables for overall and yearly generalized additive models. Full: data for 2001 and 2002 combined; Est.: estimated; other abbreviations as in Table 4

\begin{tabular}{|lccc|}
\hline Variable & Est. df & $\chi^{2}$ & $\mathrm{p}$ \\
\hline Full GAM & & & \\
25-100 m & 4.028 & 44.686 & $<0.00001$ \\
Chla & 5.379 & 60.304 & $<0.00001$ \\
Bathymetric slope & 7.577 & 42.513 & $<0.00001$ \\
100-300 m & 5.924 & 19.001 & 0.02 \\
Dist.ice & 3.609 & 60.641 & $<0.00001$ \\
Dist.inswb & 4.309 & 23.709 & 0.004 \\
2001 & & & \\
25-100 m & 4.493 & 21.792 & 0.009 \\
Chla & $<0.00001$ & 0.01 & 0.92 \\
Bathymetric slope & 4.422 & 18.142 & 0.01 \\
100-300 m & $<0.00001$ & 0.06 & 0.97 \\
Dist.ice & 5.035 & 24.614 & 0.001 \\
Dist.inswb & 4.526 & 17.931 & 0.02 \\
2002 & & & \\
25-100 m & 4.763 & 42.09 & $<0.00001$ \\
Chla & 5.571 & 48.395 & $<0.00001$ \\
Bathymetric slope & 6.756 & 35.441 & $<0.00001$ \\
100-300 m & 2.054 & 15.909 & 0.06 \\
Dist.ice & 0.7126 & 12.41 & 0.002 \\
Dist.inswb & 1.897 & 20.578 & 0.01 \\
\hline
\end{tabular}

tration was not found to have a significant relationship with whale distribution ( $p>0.92)$.

The GAM using 2002 data showed similar relationships to those found in the combined GAM (Table 6, Fig. 5C). Acoustic volume backscatter from 25 to $100 \mathrm{~m}$, surface chlorophyll a concentration and bathymetric slope were all associated with whale distribution patterns $(p<0.0001)$. Distance to the ice edge remained very significant $(p<0.002)$, while acoustic volume backscatter 100 to $300 \mathrm{~m}(\mathrm{p}<0.06)$ and distance to the inner shelf water boundary $(p<0.01)$ were still significant, but less so. The distribution of whale sightings in relation to volume backscatter levels and the marginal ice edge is shown in Fig. 3B.

The estimated smoothing curves suggested a nonlinear relationship between whale distribution and the acoustic volume backscatter levels for both 25 to 100 and 100 to $300 \mathrm{~m}$, increasing and then stabilizing at a plateau (Fig. 5). Likewise, there was a positive nonlinear relationship between whale numbers and distance to the inner shelf water boundary. The relationship between whale numbers and bathymetric slope indicated a strong relationship with whale sightings and dynamic bottom topography. Finally, the GAM indicated a strong, negative relationship between whale numbers and increasing distance from the marginal ice edge.

\section{DISCUSSION}

Over the 2 yr of our study, the distribution of baleen whales in the inner shelf waters of the WAP was most strongly linked to prey abundance and certain bathymetric/hydrographic processes that may aid in prey retention and aggregation (Fig. 3). Both tree-based and generalized additive models indicated significant relationships between observed whale numbers in 2001 and 2002 and backscattering in the upper $100 \mathrm{~m}$ of the water column (taken here as an index of the abundance of zooplankton). Both singularly (as in the tree-based models) and additively with other environmental variables (as in GAMs), a strong relationship existed between the distribution of baleen whales and their prey. When both years were combined, the whale-prey relationship was further strengthened, as was the relationship between whale relative abundance, proximity to the marginal ice edge, and increasing bathymetric slope. By using non-linear modeling techniques, we can gain further insights into the nature of the relationship between whales, prey, and their environment.

Predator aggregations most often occur as a nonlinear function of increasing prey density (Holling 1965), leading to threshold foraging behavior (Piatt \& 

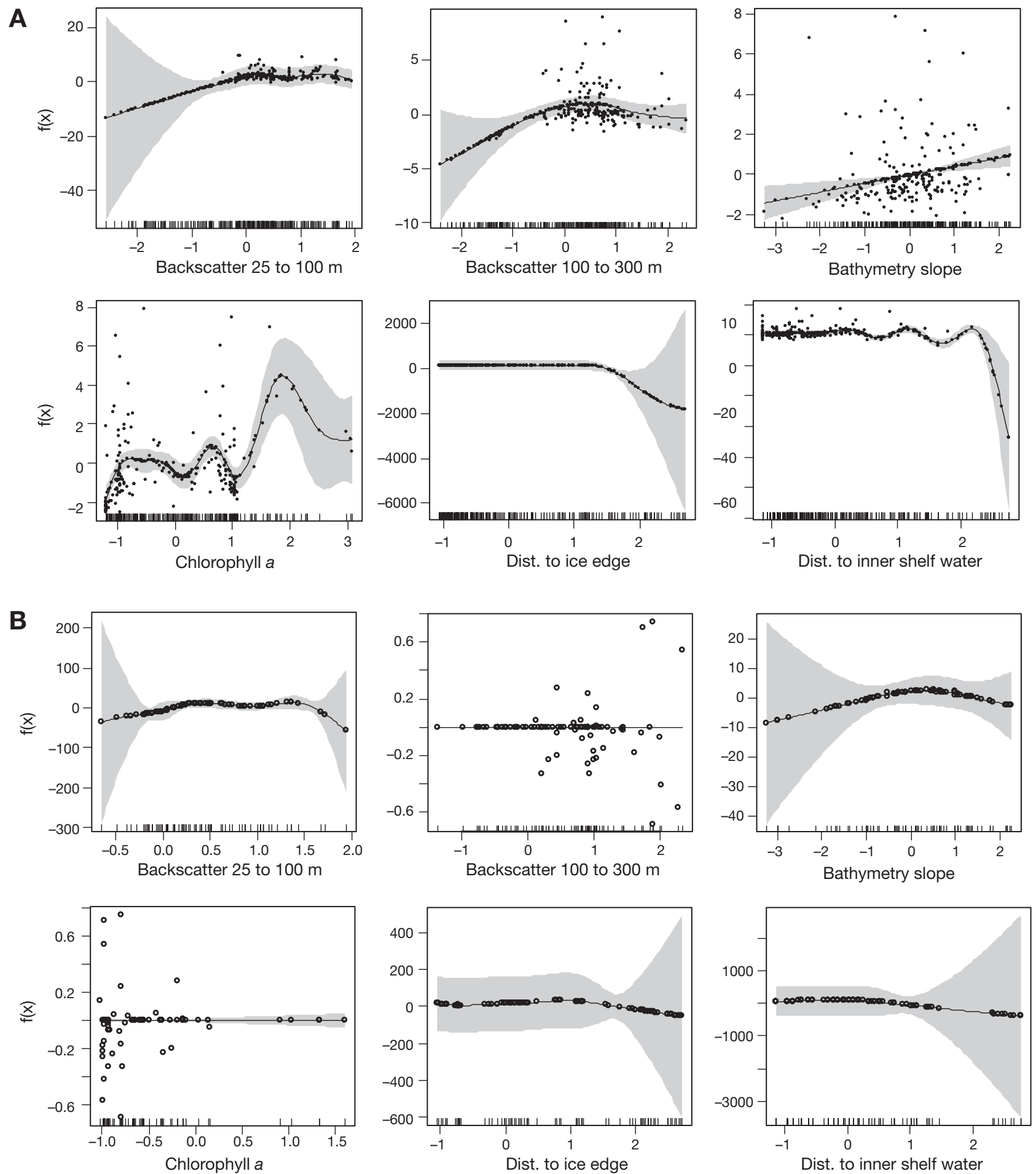

Fig. 5. Generalized additive model functions for (A) both years, (B) 2001 and (C) 2002, of cetacean sightings in relation to environmental variables. Continuous lines: smoothing curve; grey shading: $95 \%$ confidence limits. $x$-axis $=$ standardized variable [(value-mean)/standard deviation], $y$-axis fitted smooth function; along $x$-axis indicate individual sample points

Methven 1992). Piatt \& Methven (1992) documented a lower limit of prey density below which foraging by baleen whales was unprofitable and aggregation of whales did not occur. This lower limit is likely set by their foraging style of engulfing prey (Brodie et al. 1978). Piatt \& Methven's (1992) study is the only study in which baleen whale abundance is mathematically described as a function of prey density at the meso- 

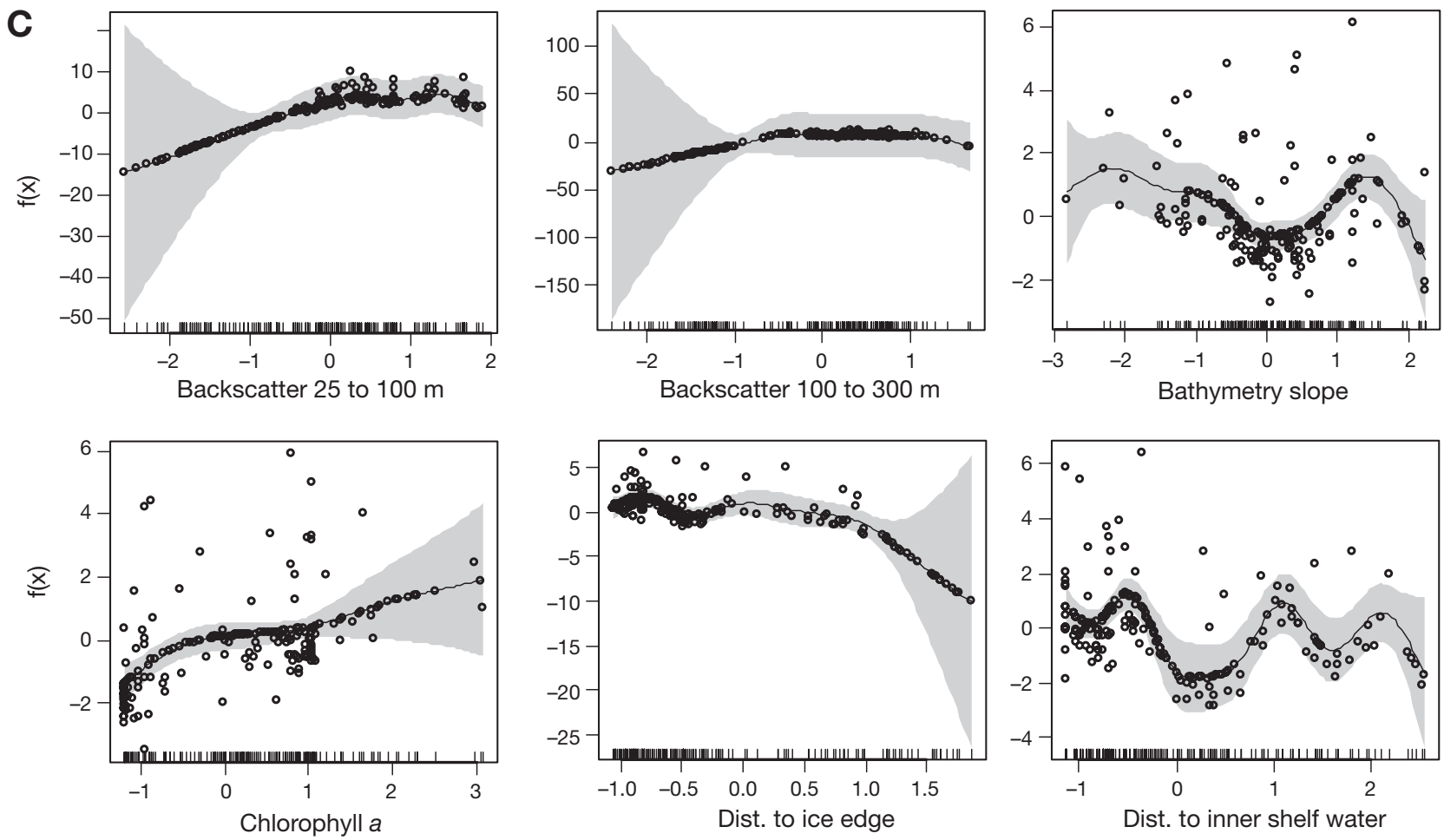

Fig. 5 (continued)

scale. Robust prey sampling techniques were employed in their study, but the authors were unable to measure the absolute density, shape and volume of the prey fields, all of which may significantly affect the response of foraging whales.

The shape of the smoothing curve that described the relationship between whale numbers and acoustic volume backscatter revealed an interesting non-linear relationship (Fig. 5). We observed a volume backscatter level below which whales were not found. Volume backscatter then increased linearly with increasing whale numbers until it reached a plateau. From these observations we hypothesize the existence of threshold levels of prey density below which whales do not forage. In other words, we may be able to determine the volume backscatter level below which it is not energetically efficient for a whale to be foraging. In order to do so, however, we would need a better sampling approach, with surveys designed to determine the true density of whales and absolute measurements of abundance and patch structure. Our approach moves beyond measures of presence/absence by using relative abundance, standardized by observation effort. Because of the resolution and averaging of our environmental and prey variables, we may miss small prey patches that could be suitable for foraging by single whales, but not large enough for foraging by multiple whales. The plateau at which increasing volume backscatter no longer leads to an increase in whale numbers may indicate another threshold level. As methods for estimating zooplankton biomass (and even the biomass of euphausiids from hydro-acoustics) improve, we will be able to investigate the actual level at which the slope of the association curve between zooplankton and whale density reaches 0 , and infer the minimum prey threshold for a given number of whales in one area. Also, it may be possible to determine the level beyond which prey density is nonlimiting to whale abundance. Pursuant to the goals of SO GLOBEC, such an understanding would greatly increase our knowledge of the predator-prey dynamics and how these relationships may be affected by large-scale environmental change.

The combination of environmental variables included in our model appears to have a great deal of predictive ability, but should be viewed with some caution. As noted in Hastie et al. (2005), the flexibility of GAMs can potentially lead to the over-fitting of data, leading to misinterpretations of the relationship between cetacean distribution and environmental structure from a single year's data. Such precaution must be considered in the light of the explanatory power of the GAM for the 2001 data, which accounted for over $98 \%$ of the deviance. The initial survey design of SO GLOBEC cruises did not explicitly include visual sighting effort, and the amount of daylight (diminishing throughout each cruise), combined with the spatial extent of the survey effort limited the number of cetacean sightings. 
Similarly, there could have been inherent spatial autocorrelation in our sighting data. If this were true, the significance of our models and the significance of the environmental variables would be suspect. Therefore, we plotted our model residuals (using both years of data) against both latitude and longitude, and found no apparent spatial patterns.

We conclude that the relationships observed in the CART and GAMs are likely to be real, but that our limited sample size may have led to over- or underrepresentation of their true importance. Efforts to constrain the degrees of freedom for each variable in the GAM could elucidate more representative relationships; however, our sample size likely limits our ability to draw any such inference. Similarly, the functional form of the relationship between whale distribution and chl a was highly significant but very non-linear, and thus it is difficult to attain any substantial appreciation of its ecological relationship.

Marguerite Bay is a dynamic environment, with complex bathymetry and high velocity coastal currents, forced at some level due to sea ice melt, small to medium sized cyclonic gyres and eddies (Beardsley et al. 2004), and episodic intrusions of circumpolar deep water onto the continental shelf and into the bay (Beardsley et al. 2004, Klinck et al. 2004). Siegel (1998) suggested that retentive processes may increase the likelihood of krill migrating back into coastal areas for the winter. Indeed, high zooplankton concentrations were associated with several of these features in 2001. The highest backscattering in 2001 was in the southern portion of the study area and within Marguerite Bay itself (Lawson et al. 2004), and high abundances of adult krill were observed in the far northern fiords of the bay (Ashjian et al. 2004). Furthermore, elevated euphausiid abundance was seen in a band 10 to $20 \mathrm{~km}$ in length along the marginal ice edge north of Alexander Island (Zhou \& Dorland 2004).

The plastic relationships between whale abundance and physical environmental features during the $2 \mathrm{yr}$ of our study highlight the dynamic and variable nature of the Antarctic marine environment. Sea ice in 2001 was limited mostly to bays and fiords, while in 2002 the previous winter's ice never fully retreated, creating very different conditions in Marguerite Bay between years. Areas of high bathymetric slope in and around Marguerite Bay consistently coincided with areas of high backscattering; including krill aggregations (see Ashjian et al. 2004 and Lawson et al. 2004). Likewise, there is a clear, increasing, significant relationship in the combined year GAM between whale distribution and bathymetric slope. From this knowledge of the relationship to zooplankton inferred from volume backscattering data (Fig. 5), we can hypothesize that whales appear to be able to track their prey, either directly or through aggregating oceanographic processes, and distribute themselves where the highest levels of prey occur. In years when the annual pack ice does not fully retreat, this boundary may continue to serve as an aggregating area for both krill and whales. Conversely, in years when the sea ice retreats completely, whales may be found in areas of highest krill abundance i.e. areas of highly dynamic bathymetry.

Satellite tracked crabeater seals in Marguerite Bay frequented areas of high zooplankton abundance, shallow water depths, and high pack ice concentrations (Burns et al. 2004). Areas of low seal use, such as the offshore shelf and middle of Marguerite Bay, also containedf fewer cetaceans and seabirds (Chapman et al. 2004, Thiele et al. 2004). However, there was a substantial temporal lag between the monitoring of satellite tagged seals and zooplankton measurements. Seabird distribution patterns during SO GLOBEC have only been assessed in relation to physical features. Chapman et al. (2004) found bird distribution to be associated with water mass structure and bathymetric variability in autumn.

The co-occurrence of sympatric species that occupy closely related ecological niches fundamentally increases the possibility of interspecific interactions in the form of competition. Murase et al. (2002) suggested that minke whales in Antarctic waters concentrate in areas where the ice edge and continental slope are coincident, intimating that prey distribution is not a primary component of their habitat selection and that they may be avoiding competition and predation. Conversely, in the same study, humpback whale distribution was associated with euphausiid concentrations regardless of spatial distribution (Murase et al. 2002). A limitation to their study, however, was the lack of sampling in nearshore, shelf and coastal waters specifically on the western side of the Antarctic Peninsula. Therefore, because of site-specific oceanographic processes, their area may not conform to the same predator and prey distribution patterns as those previously studied. To understand how these 2 whale species co-occur and partition food resources, more focused research is required to compare their spatio-temporal distribution patterns. Our study combined sightings of the 2 species, and thus did not examine interspecific relationships, but our results indicate a strong and predictable spatial and temporal correlation between humpback and minke whales and zooplankton in autumn in and around Marguerite Bay, and little indication that these species are segregated, at least at the scales we examined and with the sample size available. Further work is necessary to elucidate the nature of the relationships between humpback and minke whales and their prey. 
Our results corroborate those of Thiele et al. (2004), who showed that humpback and minke whales were associated with the sea ice boundary. Our results suggest that whales are not associated with areas far from the ice edge. We also found a significant relationship between whale distribution and zooplankton. These observations can now be used in concert to structure further hypotheses that will help to explain the linkages between whales and their environment. With a better understanding of the distribution of whales in relation to their prey, we can now investigate hypotheses as to how environmental complexity functions to enhance zooplankton concentrations and explain the strong seasonal and interannual association between these locations and the distribution of humpback and minke whales (as well as other krill predators).

We conclude that the relative abundance of humpback and minke whales is tightly linked to the distribution and abundance of their prey during autumn in Marguerite Bay. Whales may be able to locate physical features and dynamic oceanographic processes that enhance prey aggregation. The distribution of both predators and prey are influenced by physiological constraints, which help to determine habitat preferences (e.g. Boyd 1997). With this in mind, we can begin to formulate specific hypotheses regarding how humpback and minke whales may partition resources to avoid or reduce interspecific competition.

Acknowledgements. We thank the captains and crew of the ARSV 'Nathaniel B. Palmer' and RV 'Lawrence M. Gould' for their cooperation and facilitation in all aspects of SO GLOBEC. We also thank the observers and other scientific groups who helped with sightings and incollecting environmental data for both years of the study, as well as all members of the BIOMAPER-II team. Special thanks go to E. A. Treml for aiding in geospatial processing. This manuscript was enhanced by the thoughtful comments and ideas of E. E. Hofmann, and D. W. Johnston and 5 anonymous reviewers. Resources for this project were provided by the National Science Foundation Office of Polar Programs grant OPP-9910307 and the International Whaling Commission. This work represents a portion of A.S.F.'s dissertation, funded by a Duke University Marine Laboratory Fellowship.

\section{LITERATURE CITED}

Ainley DG, Wilson PR, Barton KJ, Ballard G, Nur N, Karl B (1998) Diet and foraging effort of Adélie penguins in relation to pack-ice condition in the southern Ross Sea. Polar Biol 20:311-319

Ashjian CJ, Rosenwaks GA, Wiebe PH, Davis CS, Gallager SM, Copley NJ, Lawson GL, Alatalo P (2004) Distribution of zooplankton on the continental shelf off Marguerite Bay, Antarctic Peninsula, during Austral Fall and Winter 2001. Deep-Sea Res II 51:2073-2098

Atkinson A, Siegel V, Pakhomov E, Rothery P (2004) Long-term decline in krill stock and increase in salps within the Southern Ocean. Nature 432:100-103
Beardsley RC, Limeburner R, Owens RB (2004) Drifter measurements of surface currents near Marguerite Bay on the Western Antarctic Peninsula shelf during austral summer and fall 2001 and 2002. Deep-Sea Res II 51:1947-1964

Bolmer ST, Beardsley RC, Pudsey C, Mooris P, Wiebe PH, Hofmann EE, Anderson J, Maldonado A (2004) High-resolution bathymetry map for the Marguerite Bay and adjacent west Antarctic Peninsula shelf for the Southern Ocean GLOBEC program. Woods Hole Oceanogr Inst Tech Rep WHOI2004-02.76

Boyd IL (1997) The behavioural and physiological ecology of diving. Trends Ecol Evol 12:213-217

Breiman L, Friedman JH, Olshen R, Stone CJ (1984) Classification and regression trees. Wadsworth International Group, Belmont, CA

Brierley AS, Fernandes PG, Brandon MA, Armstrong F and 8 others (2002) Antarctic krill under sea ice: elevated abundance in a narrow band just south of ice edge. Science 295:1890-1892

Brodie PF, Sameoto DD, Sheldon RW (1978) Population densities of euphausiids off Nova Scotia as indicated by net samples, whale stomach contents and sonar. Limnol Oceanogr 23:1264-1267

Burns JM, Costa DP, Fedak MA, Hindell MA and 5 others (2004) Winter habitat use and foraging behavior of crabeater seals along the Western Antarctic Peninsula. Deep-Sea Res II 51:2279-2303

Chapman EW, Ribic CA, Fraser WR (2004) The distribution of seabirds and pinnipeds in Marguerite Bay and their relationship to physical features during austral winter 2001. Deep-Sea Res II 51:2261-2278

Croxall JP, Everson I, Kooyman GL, Ricketts C, Davis RW (1985) Fur seal diving behavior in relation to vertical distribution of krill. J Anim Ecol 54:1-8

de la Mare WK (1997) Abrupt mid-twentieth-century decline in Antarctic sea-ice extent from whaling records. Nature 389:57-60

De'ath G, Fabricius KE (2000) Classification and regression trees: a powerful yet simple technique for ecological data analysis. Ecology 81:3178-3192

ESRI (Environmental Systems Research Institute) (2001) ArcGIS geostatistical analyst. Redlands, CA

Fraser WM, Hofmann EE (2003) A predator's perspective on causal links between climate change, physical forcing and ecosystem response. Mar Ecol Prog Ser 265:1-15

Guisan A, Zimmerman NE (2000) Predictive habitat distribution models in ecology. Ecol Model 135:147-186

Hamilton PK, Stone GS, Martin SM (1997) Note on a deep humpback whale Megaptera novaeangliae dive near Bermuda. Bull Mar Sci 61:491-494

Hastie TJ, Tibshirani RJ (1990) Generalized additive models. Chapman \& Hall, New York

Hastie GD, Swift RJ, Slesser G, Thompson PM, Turrell WR (2005) Environmental models for predicting oceanic dolphin habitat in the Northern Atlantic. ICES J Mar Sci 62:760-770

Hofmann EE, Costa DP, Daly KL, Torres JJ, Fraser WR (2002) US Southern Ocean global ocean ecosystem dynamics program. Oceanography 15:64-74

Holling CS (1965) The functional response of predators to prey density and its role in mimicry and population regulation. Mem Entiomolog Soc Can 45:1-60

Ichii T, Kato H (1991) Food and daily consumption of southern minke whales in the Antarctic. Polar Biol 11:479-487

Johnston DW, Friedlaender AS, Torres LG, Lavigne DM (2005a) Variation in sea ice cover on the east coast of Canada from 1969 to 2002: climate variability and implications for harp and hooded seals. Clim Res 20:200-222 
Johnston DW, Westgate AJ, Read AJ (2005b) Effects of finescale oceanographic features on the distribution and movements of harbour porpoises Phocoena phocoena in the Bay of Fundy. Mar Ecol Prog Ser 295:279-293

Kasamatsu F, Ensor P, Joyce GG, Kimura N (2000a) Distribution of minke whales in the Bellingshausen and Amundsen Seas (60 degrees W-120 degrees W), with special reference to environmental/physiographic variables. Fish Oceanogr 9:214-223

Kasamatsu F, Matsuoka K, Hakamada T (2000b) Interspecific relationships in density among the whale community in the Antarctic. Polar Biol 23:466-473

Kawamura A (1994) A review of baleen whale feeding in the Southern Ocean. Rep Int Whal Comm 44:261-271

Klinck JM, Hofmann EE, Beardsley RC, Salihoglu B, Howard S (2004) Water-mass properties and circulation on the west Antarctic Peninsula continental shelf in austral fall and winter 2001. Deep-Sea Res II 51:1925-1946

Lascara CM, Hofmann EE, Ross RM, Quetin LB (1999) Seasonal variability in the distribution of Antarctic krill, Euphausia superba, west of the Antarctic Peninsula. DeepSea Res I 46:951-984

Laws RM (1977) The significance of vertebrates in the Antarctic marine ecosystem. In: Lano GA (ed) Adaptation within Antarctic ecosystems. Smithsonian Institution, Washington, DC, $p$ 411-438

Lawson GL, Wiebe PH, Ashjian CJ, Gallager SM, Davis CS, Warren JD (2004) Acoustically-inferred zooplankton distribution in relation to hydrography west of the Antarctic Peninsula. Deep-Sea Res II 51:2041-2072

Loeb V, Seigel V, Holm-Hansen O, Hewitt R, Fraser W, Trivelpiece W, Trivelpiece S (1997) Effects of sea-ice extent and krill or salp dominance on the Antarctic food web. Nature 387:897-900

Mackintosh NA (1965) The stocks of whales. Fishing News (Books), London

Marr JWS (1962) The natural history and geography of the Antarctic krill (Euphausia superba Dana). Discov Rep 32: 33-464

Matthews LH (1937) The humpback whale, Megaptera nodosa. Discov Rep 17:7-92

Moore SE, Waite JM, Friday NA, Honkalehto T (2002) Cetacean distribution and relative abundance on the centraleastern and the southeasten Bering Sea shelf with reference to oceanographic domains. Prog Oceanogr 55:249-261

Murase H, Matsuoka K, Ichii T, Nishiwaki S (2002) Relationship between the distribution of euphausiids and baleen whales in the Antarctic (35 degrees E-145 degrees W). Polar Biol 25:135-145

Murphy EJ (1995) Spatial structure of the Southern Ocean ecosystem: predator-prey linkages in Southern Ocean food webs. J Anim Ecol 64:333-347

Nasu K (1974) Movement of baleen whales in relation to hydrographic conditions in the northern part of the North Pacific Ocean and the Bering Sea. In: Hood DW, Kelley EJ (eds) Oceanography of the Bering Sea with emphasis on renewable resources. Institute of Marine Science, University of Alaska, Fairbanks, AK, p 345-361

Nicol S, Pauly T, Bindoff NL, Wright S, Thiele D, Hosie GW, Strutton PG, Woehler E (2000) Ocean circulation off east Antarctica affects ecosystem structure and sea-ice extent. Nature 406:504-507

Parkinson CL (2002) Trends in the length of Southern Ocean sea ice seasons1979-99. Ann Glaciol 35:435-440

Editorial responsibility: Otto Kinne (Editor-in-Chief), Oldendorf/Luhe, Germany
Piatt JF, Methven DA (1992) Threshold foraging behavior of baleen whales. Mar Ecol Prog Ser 84:205-210

Qian SS, Anderson CW (1999) Exploring factors controlling the variability of pesticide concentrations in the Willamette River Basin using tree-based models. Environ Sci Techno Libr 33:3332-3340

Redfern JV, Ferguso MC, Becker EA, Hyrenbach KD and 15 others (2006) Techniques for cetacean-habitat modeling: a review. Mar Ecol Prog Ser 310:271-295

Reid K, Brierley AS, Nevitt GA (2000) An initial examination of relationships between the distribution of whales and Antarctic krill Euphausia superba at South Georgia. J Cetacean Res Manag 2:143-149

Reid K, Sims M, White RW, Gillon KW (2005) Spatial distribution of predator/prey interactions in the Scotia Sea: implications for measuring predator/fisheries overlap. DeepSea Res II 51:1383-1396

Ribic CA, Ainley DG, Fraser WR (1991) Habitat selection by marine mammals in the marginal ice-zone. Antarct Sci $3: 181-186$

Siegel V (1998) A concept of seasonal variation of krill (Euphausia superba) distribution and abundance west of the Antarctic Peninsula. In: Sahrhage D (ed) Antarctic ocean and resources variability. Springer-Verlag, Berlin, p 219-230

Thiele DC, Chester ET, Moore SE, Sirovic A, Hildebrand JA, Friedlaender AS (2004) Seasonal variability in whale encounters in the Western Antarctic Peninsula. Deep-Sea Res II 51:2311-2325

Tynan CT (1997) Cetacean distributions and oceanographic features near the Kerguelen Plateau. Geophys Res Lett 24: $2793-2796$

Tynan CT (1998) Ecological importance of the southern boundary of the Antarctic circumpolar current. Nature 392: 708-710

Tynan CT, Ainley DG, Barth JA, Cowles TJ, Pierce SD, Spear LB (2005) Cetacean distributions relative to ocean processes in the northern California Current System. DeepSea Res II 52:145-167

Uda M (1954) Studies of the relation between the whaling grounds and the hydrographical conditions. Sci Rep Whales Res Inst 9:179-187

van Franeker JA, van den Brink NW, Bathmann UV, Pollard RT, de Baar HJW, Wolff WJ (2002) Response of seabirds, in particular prions (Pachyptila sp.), to small scale processes in the Antarctic Polar Front. Deep-Sea Res II 49: 3931-3950

Wiebe $\mathrm{PH}$, Stanton TK, Greene CH, Benfield MC, Sosik HM, Austin T, Warren JA, Hammar T (2002) BIOMAPER II: an integrated instrument platform for coupled biological and physical measurements in coastal and ocean regions. IEEE J Ocean Eng 27:700-716

Wood SN (2004) Stable and efficient multiple smoothing parameter estimation for generalized additive models. J Am Stat Assoc 99:673-686

Woodley TH, Gaskin DE (1996) Environmental characteristics of north Atlantic right and fin whale habitat in the lower Bay of Fundy, Canada. Can J Zool 74:75-84

Zhou M, Dorland RD (2004) Aggregation and vertical migration behavior of Euphausia superba. Deep-Sea Res II 51: $2119-2137$

Zwally HJ, Comiso JC, Parkinson C, Campbell WJ, Carsey FD, Gloersen P (1983) Antarctic sea ice, 1973-1976: satellite passive-microwave observations. NASA Spec Publ 459:206

Submitted: August 12, 2005; Accepted: December 8, 2005

Proofs received from author(s): June 22, 2006 